\title{
SOCIO-ECONOMIC VARIABLES AND TAX COMPLIANCE IN THE SCOPE OF FISCAL SOCIOLOGY: A RESEARCH ON THE EUROPEAN UNION AND OECD*
}

\author{
Rana DAYIOĞLU ERUL ${ }^{* *}$
}

\begin{abstract}
Fiscal sociology investigates financial events from a sociological point of view and explores the effects of tax and spending policies on society and also the role and influence of the elements that constitute society in defining these policies. As the tax system and policies of each country reflect the characteristics of the country's social, political, cultural and economic structure, tax systems differ according to the characteristics of the structure of the society. Tax systems that are in line with the social structure ensure that tax compliance is achieved at a high level. From this point of view, aim of the study is defined as investigating the level of interaction of the structural elements with tax compliance. In this respect, tax compliance and socio-economic variables that affect the structure of the society are included in the study and they are analyzed using panel data analysis covering the 2008-2016 time period by making comparisons between the European Union and OECD countries. As a result of the analysis, the main point in increasing tax compliance is that the tax policies are adopted by the society, for this reason it is concluded that implementations that reflect the society need to be taken as a basis while making the regulations on the tax system.
\end{abstract}

Key Words: Fiscal sociology, tax compliance, panel data analysis, socio-economic variables.

Jel Codes: H26, K34

\section{INTRODUCTION}

Each country has its own tax system which is affected by its structure of the society and in this respect, it is important to arrange tax policies by taking into account the determinants that constitute the society's structure in social, economic, cultural, institutional, pyschological and sociological ways. If tax policies are regulated in this way, they will reach the success by tax compliance because policies that reflect the society lead higher tax compliance by making the acception of the tax system easier. This is the main idea of fiscal sociology.

Making fiscal sociological research have been taking a more important role nowadays because fiscal sociological researches that started with Ibni Khaldun in the 14th century are still ongoing and its importance has been understood by researchers. That's why, the number of new aprroaches and studies is increasing day by day.

In this study, it is aimed to find out the the importance of financial sociology in line with tax compliance. In this regard, determinants affecting tax compliance will be analyzed to measure how socio-economic variables that constitute the society's structure affect the level of

\footnotetext{
* This study is carried out within the scope of the research support given by TUBITAK (The Scientific and Technological Research Council of Turkey).

** Dr., University of Exeter, Tax Administration Research Centre, m.r.erul@exeter.ac.uk
} 


TJSSS

compliance. This is important in terms of determining which factors should be given priority and importance in the implementation of tax policies.

\section{THEORETICAL EXPLANATIONS ABOUT FISCAL SOCIOLOGY}

It is important to begin this section by reviewing the different definitions of fiscal sociology and after that, the significance of the fiscal sociology will be explained by taking into consideration the relationship between sociological perspective to fiscal events and tax policies.

\subsection{Definition of Fiscal Sociology}

As the study of society's behavior in the context of the impacts of historical events and social development (Giddens, 2011:6), sociology examines the unfolding and effects of social events not only with the social and cultural elements involved, but with fiscal elements and repercussions, as well. The main lack of the social sciences are that they generally deal with the area of related field. The main difference of fiscal sociology from other social sciences is examining together different areas. Fiscal sociology investigates the effects and outcomes that make up the field of study of fiscal sociology are to be considered in the wider context of politics, culture, religion and society (Backhaus, 2004:143). This integrative and unifying feature of financial sociology welcomes to many disciplines such as economic sociology, state sociology, anthropology, political science, financial law and public law, as well as the need to address different dimensions such as social geography, local economy and regional development (Brun, 2013:11).

Fiscal sociology can be described, as the theoretical, sociological study of tax policy formation in a very broadly way (Mumford, 2019:11). To the extent it has a predominant theme, its "central aspect" is tax compliance -this is the reason why fiscal sociology and tax compliance should be investigated together-, although the investigations run deeper than considerations of how best to effect compliance, or to prevent non-compliance (Nuta, 2018:392).

Fiscal sociology mainly focuses on political, economic, cultural, institutional, and historical influences on taxation and public expenditures (Campbell, 1993:164). Fiscal sociology should above all be concerned with the articulation between state and society with the combination of history and three rahter large tasks are involved (Padgett, 1981:76);

- An institutional analysis of the structure of governmental expenditure and/or taxation policymaking, along with a historical description of its operation and development,

- A "symptomatic" analysis of mechanisms for the representation of external group and/or class interests within the system,

- A "causal" analysis of the impact of expenditure and taxation policies on a wide variety of social phenomena such as economic growth, income distribution, the regulation of economic relations and the changing structure of the policy itself.

\subsection{Why is Sociological Approach to Tax Policies Important?}

Social, cultural and economic determinants which affect taxpayers' behavior are crucial to be considered while making policies because they have also an effect on the rate of tax collection. Thus, tax is approached as one of the most 'pervasive' relationships that exists between the citizens and the state, as 'everyone' is obliged to pay tax (Mugler, 2019:390).

Tax and expenditure policies formulated with taking into consideration cultural, legal, economic, political and social factors which reflect the society will affect tax compliance because it will be easier to attain social acceptance. This may bring success to the policies and 
practices implemented by the government. In parallel with this view, scholars acknowledge that both the policies regarding expenditures and taxation have significant effects on sociological phenomena (Campbell, 1993:164).

The importance of the interaction of fiscal sociology with taxes is explained in Figure 1, based on the assumption of an indirect tax on a certain product (e.g. bagels). Since this tax on bagels increases the demand price and decreases the supply price, the balance production level/quantity decreases from $\mathrm{Q}_{0}$ to $\mathrm{Q}_{\mathrm{t}}$. The excessive burden caused by taxation equals the area of the shaded triangle. This explanation is in line with the economic theory, but some questions have not been answered regarding the excessive tax burden yet (Backhaus, 2001:14). For example, we do not know how consumers and producers behave across the tax, what the producers do in the production process of the bagels, whether the producers and consumers develop new ideas to prevent tax, whether new products will be produced in markets with no tax, under what circumstances tax evasion will occur and what consequences it will bring. All these questions which remain unanswered will not be brought up or answered in classical tax burden analyses (Backhaus, 2001:14-15). However, these questions should be answered when applying or evaluating policies such as collecting a tax, introducing a new tax, or increasing or decreasing tax rates (Backhaus, 2001:15). This brings and proves the importance of fiscal sociology.

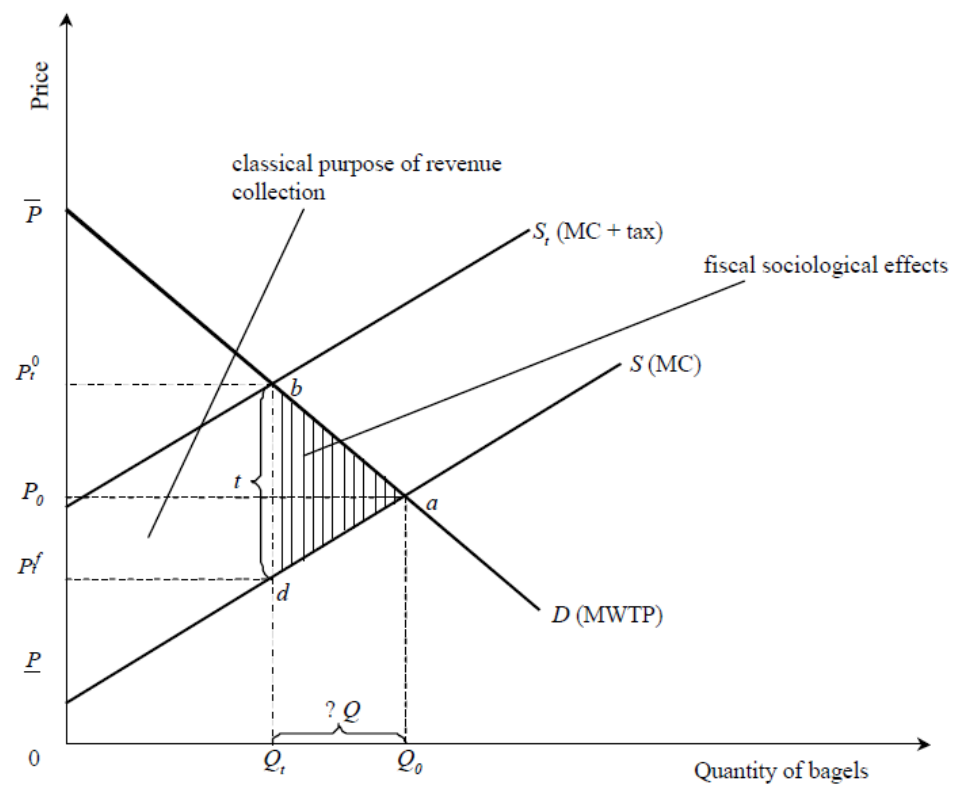

Figure 1. The Relationship Between Fiscal Sociology and Tax

Source: Backhaus, 2001:14.

As fiscal sociology focuses on tax policies with the structure of the society together, this is closely related to the rapid recognition of the regulations on tax systems in the society and the response developed against them. In this respect, it is crucial to investigate the economic, social, and cultural characteristics of the society and to evaluate the circumstances under which these policies will be implemented before putting into practice new policies. As only the policies that reflect the structure of the society can achieve success, the importance of fiscal sociology occurs in this way. 


\begin{tabular}{l} 
Year:4, Volume:4, Number:7 / 2020 \\
\hline $\begin{array}{l}\text { The } \\
\text { Socinal of } \\
\text { Science }\end{array}$
\end{tabular}

\section{DETERMINANTS OF TAX COMPLIANCE}

It is important to examine tax compliance factors to determine the variables that will be used in the analyses to be applied in this research. Tax compliance models are studied mainly in two categories, namely, economic models and psychological and behavioral models. In this section, these determinants and any other determinants which have been searched within new approaches will be examined.

Classical determinants are examined in the framework of economic models. Allingham and Sandmo (1972) were the first authors to examine the economic model of tax compliance, and the literature on the subject started with their study. The expected benefit model of Allingham and Sandmo suggests that the variables that determine tax compliance are tax control, tax penalties, risk of getting caught and punished (tax audit), tax rate and income (expected benefit).

According to Allingham and Sandmo's model, tax declaration decision is a decision under uncertainty because failure to report one's full income to the tax authorities does not automatically provoke a reaction in the form of a penalty (Allingham and Sandmo, 1972:324). Given an exogenously established income, a constant income tax rate and a constant audit probability, the taxpayer faces to two alternatives: to declare or to understate his real income; if the taxpayer chooses to declare less than his real income, he is uncertain about his final outcome due to the probability of being audited and fined for non-compliance (Batrancea $e t$ $a l ., 2012: 22)$. The authors stress that the taxpayer will evade taxes if the expected utility from evasion exceeds the expected utility from full compliance (Batrancea et al., 2012:22).

After Allingham and Sandmo's study, Yitzhaki improved the economic model and in the study of Yitzhaki, it is concluded that as the tax rate increases the income evaded decreases and in this case there is no substitution effect (Yitzhaki, 1974:201). Thus, according to the model, Yitzhaki concludes that increasing tax rates will reduce unreported income, a prediction that contradicts general belief (Saruç, 2015:46).

The expected benefit model and the Yitzhaki model were then extended by sociological factors. In the study of Juan, Lasheras and Mayo (1994), sociological variables which affect tax compliance such as age, education, being selfish or altruistic, social pressure on tax evasion, taxpayer's perception of tax burden injustice are included in the research.

After it has been understood that tax compliance is related not only to economic, but also to behavioral factors, the models focusing on the psychological and social aspects of tax compliance have started to be developed due to insufficient economic elements in explaining tax compliance. The most widely known and applied of these is prospect theory and this theory was developed by Kahneman and Tversky (1979).

Prospect theory is based on the following five main ideas; reference dependence, declining sensitivity, loss aversion, non-linear weighting of probabilities and susceptibility to framing effects (Dhami and al-Nowaihi, 2006:172). In prospect theory; not only the maximization of individual interest and individual benefit function that determines the tax payment preferences of individuals, but also psychological perception determines taxpayers' attitudes and behaviors about tax payment. In this respect, prospect theory, in comparison to to the expected benefit model, only deals with psychological factors, but not economic factors and suggests that the main determinants of tax compliance are psychological, cultural, moral, legal, religious, institutional, and political elements and costs rather than economic factors. 
According to another model which is developed by Song and Yarbrough in 1978, three determinants such as legal environment, tax ethics, opportunity and other situational factors affect tax compliance (Song and Yarbrough, 1978:444). Kirchler, Hoelzl and Wahl (2008) explained tax compliance with two main variables such as the trust in the authorities and the power of authority and differentiated tax compliance as voluntary and enforced tax compliance based on the criteria of trust and power. In their slippery slope tax compliance model, tax compliance will be low when both the power of the authorities and trust in them are at low levels. However, if an atmosphere of trust and cooperation can be established between the parties, then trust in the authority, thus voluntary tax compliance will be high (Kirchler, Hoelzl \& Wahl, 2008:212).

In 2000's, in addition to economic and psychological determinants of tax compliance, sociological determinants have started to have importance in tax compliance studies. Especially in the framework of the new approach of fiscal sociology developed in the 2000's bring up the themes of sociological sensitivity in tax policy approach, the relations between micro and macro issues, the relations between constitutional issues and fiscal sociology and the place of bureaucratic regulations in financial issues (McLure, 2003:6-7). This new approach includes interdisciplinary relationships of the fields such as economics, political science, law, history, and public policy in addition to sociology (Martin et al., 2009:2) and focuses on facts that can be measured at the level of society rather than the individual. Thus, sociological approaches and studies have become more important in recent years.

Some recent reports published by OECD (OECD, 2004; OECD, 2014) suggest that economic factors, as well as external factors such as social perceptions, international changes, media and social changes have an impact on tax compliance and clearly indicate sociological variables among the factors with an effect on tax compliance. OECD made a classification about the determinants of tax compliance in five categories such as business profile, industry, sociological factors, economic factors and psychological factors.

\begin{tabular}{|c|c|c|c|c|}
\hline $\begin{array}{c}\text { Business } \\
\text { profile }\end{array}$ & $\begin{array}{l}\text { Industry } \\
\text { factors }\end{array}$ & $\begin{array}{c}\text { Sociological } \\
\text { factors }\end{array}$ & $\begin{array}{l}\text { Economic } \\
\text { factors }\end{array}$ & $\begin{array}{c}\text { Psychological } \\
\text { factors }\end{array}$ \\
\hline $\begin{array}{l}\text { - Structure - } \\
\text { sole trader, } \\
\text { partnership, } \\
\text { company, trust } \\
\text { - Size and age } \\
\text { of the business } \\
\text { - The type of } \\
\text { activities it } \\
\text { carries out } \\
\text { - Focus - local } \\
\text { versus } \\
\text { international } \\
\text { - Its financial } \\
\text { data - capital } \\
\text { investment }\end{array}$ & $\begin{array}{l}\text { - The } \\
\text { definition/size of } \\
\text { the industry } \\
\text { - Major } \\
\text { participants in the } \\
\text { industry } \\
\text { - Profit margins } \\
\text { - Cost structures } \\
\text { - Industry } \\
\text { regulation } \\
\text { - Working patterns } \\
\text { - Industry issues } \\
\text { such as levels of } \\
\text { competition, } \\
\text { seasonal factors and } \\
\text { infrastructure issues }\end{array}$ & $\begin{array}{l}\text { - Cultural norms } \\
\text { - Ethnic } \\
\text { background } \\
\text { - Attitude to } \\
\text { government } \\
\text { - Age, Gender } \\
\text { - Educational } \\
\text { level }\end{array}$ & $\begin{array}{l}\text { - Investment } \\
\text { - Demographic } \\
\text { interest rates } \\
\text { - The tax } \\
\text { system } \\
\text { - Government } \\
\text { policies } \\
\text { - International } \\
\text { influence } \\
\text { - Inflation } \\
\text { - Markets }\end{array}$ & $\begin{array}{l}\text { - Greed, Risk, } \\
\text { Fear, Trust } \\
\text { - Values } \\
\text { - Fairness/Equity } \\
\text { - Opportunity to } \\
\text { evade }\end{array}$ \\
\hline
\end{tabular}

Figure 2. Factors Affecting Tax Compliance

Source: OECD, 2004:40. 
Determinants shown in the figure include all the elements affecting tax compliance. These elements consist of social and economic variables and the important issue is that in addition to economic and psychological factors, sociological factors should be taken into consideration while measuring the effects of tax compliance. Since these variables are shaped according to the socio-economic structure of the society, sociological research-society structure-fiscal sociology takes an important role for tax compliance.

\section{TESTING THE EFFECTS OF SOCIO-ECONOMIC FACTORS ON TAX COMPLIANCE}

\subsection{Literature}

Many international studies have been made so far to measure the effects of different variables on tax compliance. In this part of the study, these studies will be examined shortly to be a guide while determining the variables for the analysis which is planned. There are many studies that have been made so far but only the studies which are thought to be useful for the analysis.

Table 1. Previous Studies About Tax Compliance

\begin{tabular}{|c|c|c|c|c|}
\hline Author(s) & Year & Variables & Method & Results \\
\hline $\begin{array}{l}\text { Grasmick and } \\
\text { Green }\end{array}$ & 1980 & $\begin{array}{l}\text { Illegal behaviour, perceived certainty of } \\
\text { arrest, perceived severity of } \\
\text { punishment, threat of social } \\
\text { disapproval, moral commitment to the } \\
\text { norm }\end{array}$ & Survey & $\begin{array}{l}\text { The authors present data which suggests that the effects of } \\
\text { all the variables are positive and additive to the previous } \\
\text { studies. }\end{array}$ \\
\hline $\begin{array}{l}\text { Spicer and } \\
\text { Becker }\end{array}$ & 1980 & Tax rates and fiscal inequity & $\begin{array}{l}\text { Experimental } \\
\text { method }\end{array}$ & $\begin{array}{l}\text { The percentage of taxes evaded is highest among those who } \\
\text { are told that their tax rates are higher than average and } \\
\text { lowest among those told their tax rates are lower than } \\
\text { average. The results of the experiment support the } \\
\text { hypothesis that indicates the amount of taxes evaded will } \\
\text { increase for victims of fiscal inequity but decrease for } \\
\text { beneficiaries of fiscal inequity. }\end{array}$ \\
\hline $\begin{array}{l}\text { Mason and } \\
\text { Calvin }\end{array}$ & 1984 & $\begin{array}{l}\text { The fairness of the tax system, } \\
\text { likelihood of getting caught when } \\
\text { cheating, income, highness of tax rates }\end{array}$ & Survey & $\begin{array}{l}\text { Analysis suggests that both satisfied and dissatisfied } \\
\text { taxpayers remain honest because they are afraid of getting } \\
\text { caught. The results show that moral commitment to obey the } \\
\text { law is strongest incentive. In addition to this, fear of } \\
\text { informal sanctions (from peers, the community and from the } \\
\text { stress of getting caught) is one of the most powerful } \\
\text { predictors of conformity with tax laws. }\end{array}$ \\
\hline $\begin{array}{l}\text { Dubin, Graetz } \\
\text { and Wilde }\end{array}$ & 1987 & $\begin{array}{l}\text { Audit rate, percent of the adult } \\
\text { population with a high school } \\
\text { education, percent of population over } \\
45, \text { the unemployment rate and percent } \\
\text { of work force employed in } \\
\text { manufacturing and per capita income }\end{array}$ & $\begin{array}{l}\text { Time series } \\
\text { analysis }\end{array}$ & $\begin{array}{l}\text { They find out that the audit rate is endogeneous, there is a } \\
\text { deterrent effect associated with increases in the audit rate, } \\
\text { compliance increases with per capita income, but at a } \\
\text { decreasing rate, peaking below the maximum per capita } \\
\text { income, there is a negative time trend in the audit rate and in } \\
\text { compliance. }\end{array}$ \\
\hline $\begin{array}{l}\text { Dubin and } \\
\text { Wilde }\end{array}$ & 1988 & $\begin{array}{l}\text { Audit, unemployment rate, percentage } \\
\text { of non-white, percentage } \\
\text { manufacturing, age and education }\end{array}$ & $\begin{array}{l}\text { Cross section } \\
\text { analysis }\end{array}$ & $\begin{array}{l}\text { They find significant deterrent effects of auditing on } \\
\text { noncompliance. }\end{array}$ \\
\hline $\begin{array}{l}\text { Alm, Jackson } \\
\text { and Mckee }\end{array}$ & 1992 & $\begin{array}{l}\text { Tax rate, audit rate, fine rate, income, } \\
\text { changes in and benefits from public } \\
\text { goods }\end{array}$ & $\begin{array}{l}\text { Experimental } \\
\text { method }\end{array}$ & $\begin{array}{l}\text { Tax compliance increases in income and audit rates and } \\
\text { decreases in tax rates. Compliance is also greater when the } \\
\text { individuals have some benefits from a public good funded } \\
\text { by their tax payments, whereas changes in fine rates appear } \\
\text { to have little effect on compliance behaviour. }\end{array}$ \\
\hline $\begin{array}{l}\text { Muter, Sakınç } \\
\text { ve Çelebi }\end{array}$ & 1993 & $\begin{array}{l}\text { Perception of tax policies, tax ethics, } \\
\text { tax burden, perceptions about tax } \\
\text { system, efficiency of audits, relations } \\
\text { between taxpayers and the authority }\end{array}$ & Survey & $\begin{array}{l}\text { The unfairness of the tax system is most inportant issue } \\
\text { among the complaints of taxpayers regarding the tax system } \\
\text { and the reasons of not being compliant. }\end{array}$ \\
\hline
\end{tabular}




\begin{tabular}{|c|c|c|c|c|}
\hline Kamdar & 1995 & $\begin{array}{l}\text { Income, marginal tax rates, source of } \\
\text { income, wages, interest and dividend } \\
\text { income, fines }\end{array}$ & $\begin{array}{l}\text { Cross section } \\
\text { analysis }\end{array}$ & $\begin{array}{l}\text { There is an inverse relationship between tax rates and } \\
\text { compliance, taxpayer behaviour is affected by } \\
\text { noncompliance opportunities, third-party information } \\
\text { reporting to be an effective deterrent to noncompliance, but } \\
\text { cast doubt on the presumption that lower marginal rates led } \\
\text { to greater compliance. }\end{array}$ \\
\hline $\begin{array}{l}\text { Scholz and } \\
\text { Lubell }\end{array}$ & 1998 & $\begin{array}{l}\text { Political factors (trust in citizens, trust } \\
\text { in government, tax fairness, tax equity, } \\
\text { civic duty, political efficacy), fear and } \\
\text { duty (tax duty,opportunity, occupation), } \\
\text { government residual }\end{array}$ & $\begin{array}{l}\text { Survey- } \\
\text { regression } \\
\text { analysis }\end{array}$ & $\begin{array}{l}\text { This study shows that trust in government and trust in other } \\
\text { citizens significantly influence tax compliance, even after } \\
\text { controlling for duty, fear, selection bias, and potential } \\
\text { endogeneity effects. }\end{array}$ \\
\hline Feld and Frey & 2002 & $\begin{array}{l}\text { Tax fines, behaviour of the tax } \\
\text { authority to taxpayers, political } \\
\text { participation rights }\end{array}$ & Survey & $\begin{array}{l}\text { The results indicate that the differences in the treatment of } \\
\text { taxpayers by tax authorities can be explained by differences } \\
\text { in political participation rights as well. The psychological } \\
\text { contract is based on a relationship of trust and if the } \\
\text { psychological tax contract is at stake, respectful treatment } \\
\text { and trust are strong deterrence and all in all these will bring } \\
\text { tax compliance because tax compliance is a contract } \\
\text { between tax authority and taxpayers. }\end{array}$ \\
\hline Park and Hyun & 2003 & $\begin{array}{l}\text { Actual income, tax rate, fine rate, audit } \\
\text { rate, public goods, social norm }\end{array}$ & $\begin{array}{l}\text { Experimental } \\
\text { method }\end{array}$ & $\begin{array}{l}\text { It is indicated that taxpayers have the same degree of } \\
\text { compliance regardless of their income levels, both tax audit } \\
\text { and penalty rate are important deterrences from tax evasion, } \\
\text { although the penalty rate is more effective, taxpayers have a } \\
\text { strong tendency for a free-ride, tax education is one of the } \\
\text { effective tools to induce taxpayers to comply more. }\end{array}$ \\
\hline Kolodziej & 2011 & $\begin{array}{l}\text { External factors (referred to economic } \\
\text { variables such as tax rates and income) } \\
\text { and internal factors (related to } \\
\text { psychological features such as } \\
\text { knowledge, motivational postures) }\end{array}$ & Survey & $\begin{array}{l}\text { The research showed positive correlation between economic } \\
\text { knowledge in the scale of economic rights and relation and } \\
\text { posture of commitment in respect of tax. }\end{array}$ \\
\hline Çevik & 2012 & $\begin{array}{l}\text { Interaction with state and political } \\
\text { system, interaction with society and } \\
\text { social capital, personal values and } \\
\text { norms }\end{array}$ & Survey & $\begin{array}{l}\text { It is founded that the social and political environment and } \\
\text { the individual values and norms of the taxpayer are } \\
\text { important in explaining the tax compliance. }\end{array}$ \\
\hline $\begin{array}{l}\text { Bobek, } \\
\text { Hageman and } \\
\text { Kelliher }\end{array}$ & 2013 & $\begin{array}{l}\text { Social norms (personal, descriptive, } \\
\text { injunctive, subjective norms), } \\
\text { demographic factors (age, income, } \\
\text { education, politiccal philosophy), } \\
\text { fairness of tax system, tax audit, risk } \\
\text { preferences }\end{array}$ & Survey & $\begin{array}{l}\text { The study shows that social norms have important direct and } \\
\text { indirect effects on tax compliance behavior. Only subjective } \\
\text { norms and personal norms directly affect taxpayers' } \\
\text { compliance intentions. Descriptive and injunctive norms are } \\
\text { related to subjective and/or personal norms; however, they } \\
\text { do not have a direct effect on tax compliance intentions. }\end{array}$ \\
\hline Saad & 2014 & $\begin{array}{l}\text { Taxpayers' view on their level of tax } \\
\text { knowledge, perceived complexity of } \\
\text { tax systems and the underlying reasons } \\
\text { of non-compliance behavior }\end{array}$ & $\begin{array}{l}\text { Telephone } \\
\text { interviews }\end{array}$ & $\begin{array}{l}\text { Taxpayers have inadequate technical knowledge and } \\
\text { perceive tax system as complex. Tax knowledge and tax } \\
\text { complexity are viewed as contributing factors towards non- } \\
\text { compliance behaviour. }\end{array}$ \\
\hline $\begin{array}{l}\text { Alm, } \\
\text { Bernasconi, } \\
\text { Laury, Lee and } \\
\text { Wallace }\end{array}$ & 2016 & $\begin{array}{l}\text { The rate of tax audit and tax rates, } \\
\text { release of photos of tax evaders to all } \\
\text { subjects along with information on the } \\
\text { extent of their non-compliance) }\end{array}$ & $\begin{array}{l}\text { Experimental } \\
\text { method }\end{array}$ & $\begin{array}{l}\text { The results provide strong support for the notion that public } \\
\text { shame is an additional deterrent to tax evaders, beyond } \\
\text { the traditional enforcement tools of higher audit rates and } \\
\text { enhanced penalty rates. }\end{array}$ \\
\hline $\begin{array}{l}\text { Yong and } \\
\text { Martin }\end{array}$ & 2016 & $\begin{array}{l}\text { Cultural diversity, individualism and } \\
\text { collectivism }\end{array}$ & $\begin{array}{l}\text { Qualitative } \\
\text { research }\end{array}$ & $\begin{array}{l}\text { Interview findings demonstrate that individualism and } \\
\text { collectivism can not be used as a generic concept in } \\
\text { determining tax compliance behaviours, but rather specific } \\
\text { features of individualism-collectivism may be used in order } \\
\text { to identify tax behavioural differences between ethnic } \\
\text { groups. }\end{array}$ \\
\hline $\begin{array}{l}\text { Andrighetto, } \\
\text { Zhang, Ottone, } \\
\text { Ponzano, } \\
\text { D'Attoma, } \\
\text { Steinmo } \\
\end{array}$ & 2016 & $\begin{array}{l}\text { Tax rate, redistribution, audit, age, } \\
\text { belief, gender }\end{array}$ & $\begin{array}{l}\text { Experimental } \\
\text { method }\end{array}$ & $\begin{array}{l}\text { The average level of tax evasion (as a measure of ordinary } \\
\text { dishonesty) does not differ significantly between Swedes } \\
\text { and Italians. While Swedes are more likely to be either } \\
\text { completely honest or completely dishonest in their fiscal } \\
\text { declarations, Italians are more prone to fudging. }\end{array}$ \\
\hline $\begin{array}{l}\text { Pukeliene and } \\
\text { Kazemekaityte }\end{array}$ & 2016 & $\begin{array}{l}\text { Tax morale, trust, power, economic } \\
\text { development, power distance, } \\
\text { individualism, masculinity, uncertainty } \\
\text { avoidance }\end{array}$ & $\begin{array}{l}\text { Panel data } \\
\text { anaylsis }\end{array}$ & $\begin{array}{l}\text { Research suggests that tax morale, socio-cultural } \\
\text { determinants and the relationship between tax authority and } \\
\text { taxpayers have an overall significant impact on tax } \\
\text { behaviour in European Union (EU) countries. }\end{array}$ \\
\hline
\end{tabular}




\begin{tabular}{|l|l|l|l|l|}
\hline $\begin{array}{l}\text { D'Attoma, } \\
\text { Volintiru and } \\
\text { Steinmo }\end{array}$ & 2017 & $\begin{array}{l}\text { Gender, tax rate, levels of legal and } \\
\text { social equality, income, trust in } \\
\text { government, redistribution }\end{array}$ & $\begin{array}{l}\text { Experimental } \\
\text { method }\end{array}$ & $\begin{array}{l}\text { The results reveal that women are significantly more } \\
\text { compliant than men in all countries. The difference between } \\
\text { men's and women's behavior is not significantly different in } \\
\text { more gender neutral countries than in more traditional } \\
\text { societies. }\end{array}$ \\
\hline D'Attoma & 2018 & $\begin{array}{l}\text { Tax rate, redistribution, economic } \\
\text { major, quality of institutions, past } \\
\text { participation, age, prosociality }\end{array}$ & $\begin{array}{l}\text { Experimental } \\
\text { method }\end{array}$ & $\begin{array}{l}\text { Contrary to cultural explanations for tax compliance, when } \\
\text { controlling the institutional environment there is no } \\
\text { difference in tax compliance. It is concluded that } \\
\text { individuals' relationship to their states shapes these } \\
\text { behavioral differences in tax compliance. }\end{array}$ \\
\hline
\end{tabular}

Surveys are generally applied in these studies as a method of measuring whereas econometric methods are rarely used. In this respect, the method that will be used in this study will be a supportive issue to make it different from others.

\subsection{Aim, Method and Variables}

The aim of this study is to examine the relationship between structural factors and tax compliance based on its theoretical framework. The structural elements include various socioeconomic elements on the basis of theories examining tax compliance and in line with the OECD assessments. The aim of the analysis is investigating the effects that the socioeconomic structural factors might have on tax compliance and measuring its direction and magnitude. Because only tax systems reflecting and including structural elements can achieve success.

The study covers the period of 2008-2016 which means that the dimension of time extends to nine years. Since data of some variables could only be founded from the year of 2008, the period starts from this year. As the study has both horizontal section and time dimensions, the method of panel data analysis is chosen and Stata is used for the analysis.

The data included in the analysis to measure the effects of variables on tax compliance within the framework of the models created are analyzed through a classification of the countries for more effective results. That's why, countries are classified as European Union (EU) and OECD countries. 28 countries $^{1}$ are included in EU group and 36 countries $^{2}$ are included in OECD group. The reason of choosing these groups is that the countries share many commonalities. Despite of the fact that each nation has its own identity and ideas, they are similar in many ways. Especially EU countries have similar lifestyles, cultural heritages and socio and economic structure such as higher education levels, strict rules, economic growth rates etc. For these reasons, it is important to search fiscal sociological effects for the countries included in the analysis and this study is exactly focuses on this aim.

The dependent variable is $\operatorname{tax}_{i t}$, indicates paying taxes rank and as it shows both the costs of taxes and the level of tax compliance for businesses, in this study it is indicated as tax compliance determinant. For this variable, $t$ is time, and $i$ is the country, thus it shows the level of tax compliance in a country during a time period. The data set is developed using the

\footnotetext{
${ }^{1}$ Austria, Belgium, Bulgaria, Croatia, Cyprus, Czech Republic, Denmark, Estonia, Finland, France, Germany, Greece, Hungary, Ireland, Italy, Latvia, Lithuania, Luxemburg, Malta, Netherlands, Poland, Portugal, Romania, Slovakia, Slovenia, Spain, Sweden, United Kingdom.

${ }^{2}$ Australia, Austria, Belgium, Canada, Chile, Czech Republic, Denmark, Estonia, Finland, France, Germany, Greece, Hungary, Iceland, Ireland, Israel, Italy, Japan, Korea, Latvia, Lithuania, Luxemburg, Mexico, Netherlands, New Zealand, Norway, Poland, Portugal, Slovakia, Slovenia, Spain, Sweden, Switzerland, Turkey, United Kingdom, United States.
} 
PricewaterhouseCoopers $(\mathrm{PwC})$ and the "Paying Taxes" reports of the World Bank ${ }^{3}$. These reports state the importance of both the costs of taxes and the level of tax compliance for businesses. Therefore, the index was measured as the "overall paying taxes rank" covering all the sub-variables of the total rate of taxes, time needed for tax compliance, and the number of tax payments (PwC and World Bank, 2014:8). In the measurements of this index, all taxes and social security premiums paid by medium-sized enterprises (at federal, central, or local level) are included (PwC and World Bank, 2015:100).

Reports show the tax compliance variable according to the country rankings included in the analysis that year. For example, if 180 countries are included in the analysis that year, a particular country's score is calculated according to its rank among 180 countries. In the analysis conducted as part of the study, this variable is taken into consideration as a percentage value for consistency with other variables.

The sub-variables showing the level of tax compliance, they are determined as follows (PwC and World Bank, 2014:124-126):

- Total tax rate: when calculating the total tax rate, the costs of all taxes including the corporate tax, taxes paid by the employer on behalf of the employee and social security contributions (including pension funds), property and municipal taxes and motor vehicle taxes. However, withholding taxes, such as personal income tax, are not included. The total tax rate is calculated by dividing the total enterprise tax by profit.

- Time needed for tax compliance: the time concept for the variable is expressed in hours. This variable includes the corporate tax, VAT or sales tax, and taxes on wage earners in terms of the time needed to prepare and submit the statement and issue the tax payment (online or in tax administration).

- Number of tax payments: this variable contains information on the total number of taxes and social security premiums paid, payment method, frequency of payments and frequency of filing a declaration. Since most medium-sized enterprises prefer to submit an electronic statement, these are the statements taken into consideration in the calculations.

As for the independent variables to be used in the analysis, they are determined as follows:

$X_{1 i t}=a u_{i t}$ (strength of auditing and reporting standards): demonstrates the strength of audit and reporting standards, with data based on the Global Competitiveness Report prepared by the World Economic Forum. The index measures the effectiveness of audits, as well as the applicability of accounting standards. The index values are shown on a scale of 1 to 7 in the reports, 1 being the lowest and 7 the highest in terms of the power of audit and reporting standards. This scale is the product of a study with 13.877 surveys conducted in 135 countries. In this study, this variable was taken as a range with the maximum value of 7 and was converted to the maximum value of 100 to secure its compatibility with other variables.

$X_{2 i t}=t r_{i t}$ (freedom to trade internationally): the international free trade variable was created using Fraser Institute data. It comprises variables such as the tariffs, trade barriers, black market exchange rates, control of the circulation of people and capital. In today's modern world, freedom to trade with people in other countries is an important ingredient of economic

\footnotetext{
${ }^{3}$ All reports beginning with the Paying Taxes 2010 through Paying Taxes 2018 were used to obtain data and the title of each report contains the data for the two previous periods. For example, Paying Taxes 2018 report includes data for 2016 .
} 
freedom because when governments impose restrictions that reduce the ability of their residents to engage in voluntary exchange with people in other countries, economic freedom is diminished (Gwartney et al, 2018:5). The variable comprised a range of 0-10, but was converted to one with the maximum value of 100 in order to secure its compatibility with other variables.

$X_{3 i t}=l a w_{i t}($ rule of law): the rule of law is one of the variables defined by Fraser Institute. As it is one of the determinants which forms personal freedom (and human freedom as well), it is expected that the increase in the variable will increase tax compliance. As a matter of fact, this variable is included in the analysis to represent the variable of power of authority and how effective and strong the rules of law are. The rule of law is an essential condition of freedom that protects the individual from coercion by others (Vasquez and Porcnik, 2018:18). The sub-variables accounted for in the formulation of this variable include the fairness and speed of the judicial process, civil justice, criminal justice, protection of intellectual property rights, trust in the judiciary and law enforcement systems, and trust in the legislative process.

$X_{4 i t}=e d u_{i t}($ education index $)$ : the education index shows the level of education in the country $\mathrm{i}$ during the $t$ period and is taken from the Legatum Institute data. The index was prepared with consideration of the following: access to education (wide range and accessibility of educational services, adult and young literacy rate, girls' schooling rate as compared to that of boys, Gini coefficient in the distribution of educational services), quality of education (citizen perceptions of the learning level of children, quality of primary and secondary education, rate of completion of primary education, degree of satisfaction with local schools, number of the best universities, international reputation of the universities) and the human capital of the workforce (skills in the workforce promoting research and development, years in secondary school per worker, higher education level per worker, the percentage of students in the secondary education age group and enrolled in technical/vocational schools) (Legatum Institute, 2017:54). The education index is on a range of 0 to 100, with 0 representing the lowest and 100 the highest level of education in the country. As the increase in education level improves the tax ethics and awareness of citizens, tax compliance is expected to increase in parallel with it.

$X_{5 i t}=$ gen $_{i t}$ (gender inequality index): gender inequality index is an inequality index. It measures gender inequalities in three important aspects of human development-reproductive health, measured by maternal mortality ratio and adolescent birth rates; empowerment, measured by proportion of parliamentary seats occupied by females and proportion of adult females and males aged 25 years and older with at least some secondary education; and economic status, expressed as labour market participation and measured by labour force participation rate of female and male populations aged 15 years and older ${ }^{4}$. The index ranges from 0 , where women and men fare equally, to 1 , where one gender fares as poorly as possible in all measured dimensions. In this respect, these values are converted to values on 100.

$X_{6 i t}=s c_{i t}($ social capital): social capital index is created by Legatum Institute and is among the institutional indexes. With all the indexes examined by the Legatum Institute considered, the social capital is the second variable showing the highest increase after the business environment in the last decade (Legatum Institute, 2017:52). As a matter of fact, the interaction among the members of a nation, their trust and respect for one another and the

\footnotetext{
${ }^{4}$ For detailed information see UNDP, http://hdr.undp.org/sites/default/files/hdr2018_technical_notes.pdf.
} 
support they receive from their social environment are all representative of the level of welfare, hence the economic growth in that particular country (Legatum Institute, 2017:52).

The variables taken into consideration when creating the social capital index are personal and social relationships (perceptions about the possibility of making friends, the extent of expecting help of family and friends, the frequency of helping strangers, the frequency of informal financial assistance), social norms (social conformity, social commitment, trust for the police and similar institutions, the way people treat each other, the level of trust and respect), and civic participation (donations to charities, the level of volunteerism, frequency of statement of opinion at the level of public officers, and voting) (Legatum Institute, 2017:52). The social capital index is on a range of 0 to 100, with 0 being the lowest and 100 the highest value and is expected to increase in parallel with tax compliance.

\subsection{Model}

In creating the model, during the measurement of the correlation degrees between tax compliance and social and economic variables, it is ensured that the variables are minimally related to each other. The interactions among variables are measured to minimize the potential for the issue of multiple linear connections and they were found to be very weak, weak, or medium in intensity. In this respect, the relationship between tax compliance and the independent variables used in the analysis are examined as economic and social variables respectively, as follows:

$\operatorname{tax}_{i t}=\beta_{0}+\beta_{1} a u_{i t}+\beta_{2} t r_{t}+\beta_{3} l a w_{i t}+\beta_{4} e d u_{i t}+\beta_{5} g e n_{i t}+\beta_{6} s c_{i t}+u_{i t}$

In the model; strength of auditing and reporting standards and freedom to trade internationally are the variables which reflect economic variables; in addition, rule of law, education index, gender inequality index and social capital indicate the social variables.

To select the right model for the analysis, the specification tests are applied for the country groups and tested the effects of individual and time factors. According to the results obtained from the tests, one-way random effect model is used for EU countries and two-way fixed effect model is used for OECD countries.

After testing the problems of varying variance (heteroscedasticity), auto-correlation, or interdivisional correlation (horizontal cross-sectional dependence) ${ }^{5}$ and deciding that at least one of them is occurred, it is concluded that the final results should be obtained by applying resistant estimators according to the test results ${ }^{6}$.

\section{RESULTS OF THE ANALYSIS}

Various methods are proposed for resistant estimators in the field literature, however, the Beck-Katz (1995) estimator was used in this study as one of the most widely used methods. The results of the model obtained with the Beck-Katz method are shown in Table 2.

According to the results, we may see that the explanatory power of the model is quite similar for the two country groups and it is about \%44, which in turn is an indication that the

\footnotetext{
${ }^{5}$ In order to test the variance, the modified Wald test was tested with the constant effects model; the Levene, Brown, and Forsythe tests were used in the random effects model; both in the constant and random effect models the autocorrelation was tested using the Bhargava, Franzini, and Narendranathan's Durbin Watson and BaltagiWu's Local Best Invariant Tests; and the Pesaran test was used in both models to test the interdivisional correlation.

${ }^{6}$ For the test results, see the "Appendix".
} 
variables' explanatory power is enough for the analysis and the variables are strong enough to explain the model for both the EU and OECD.

Table 2. Final Results

\begin{tabular}{|c|c|c|c|c|c|c|}
\hline Variable & \multicolumn{3}{|c|}{$\mathbf{E U}$} & \multicolumn{3}{|c|}{ OECD } \\
\hline $\operatorname{tax}$ & Coefficient & $\begin{array}{l}\text { Stand. } \\
\text { Error }\end{array}$ & t-stat. & Coefficient & $\begin{array}{l}\text { Stand. } \\
\text { Error }\end{array}$ & t-stat. \\
\hline$a u$ & $\begin{array}{l}-0.1236 \\
(0.378)\end{array}$ & 0.1402 & -0.88 & $\begin{array}{c}0.1922 * * * \\
(0.006)\end{array}$ & 0.0700 & 2.74 \\
\hline$t r$ & $\begin{array}{c}0.8105 * * * \\
(0.009)\end{array}$ & 0.3083 & 2.63 & $\begin{array}{c}0.6929 * * * \\
(0.000)\end{array}$ & 0.1319 & 5.25 \\
\hline law & $\begin{array}{c}0.6448 * * * \\
(0.000)\end{array}$ & 0.1517 & 4.25 & $\begin{array}{c}0.6640 * * * \\
(0.000)\end{array}$ & 0.0627 & 10.58 \\
\hline edu & $\begin{array}{c}-0.1978 \\
(0.498)\end{array}$ & 0.2920 & -0.68 & $\begin{array}{c}-0.8874 * * * \\
(0.000)\end{array}$ & 0.1802 & -4.92 \\
\hline gen & $\begin{array}{r}-0.0470 \\
(0.845)\end{array}$ & 0.2403 & -0.20 & $\begin{array}{c}0.1685^{*} \\
(0.064)\end{array}$ & 0.0911 & 1.85 \\
\hline$s c$ & $\begin{array}{c}0.4847 * * \\
(0.025)\end{array}$ & 0.2160 & 2.24 & $\begin{array}{c}0.8358^{* * *} \\
(0.000)\end{array}$ & 0.0798 & 10.47 \\
\hline Fixed & $\begin{array}{c}-49.8935 \\
(0.113)\end{array}$ & 31.466 & -1.59 & $\begin{array}{c}-37.1331^{* * * *} \\
(0.000)\end{array}$ & 10.3088 & -3.60 \\
\hline $\mathbf{R}^{2}$ & 0.4495 & & & 0.4492 & & \\
\hline
\end{tabular}

Note: $* * *, * *$ and $*$ indicate that the null hypothesis is rejected in $1 \%, 5 \%$ and $10 \%$, respectively.

First of all, the variable of audit is statistically significant only for OECD countries and one unit increase in audit has a positive effect (0.1922 unit increase) in the same direction on tax compliance. This positive effect is in line with the prediction of the expected benefit model that the increase in audit rates reduces the amount of tax evasion and the results obtained are in accordance with the theory, in spite of some existing literature to the effect that audits have negative or zero effect on tax compliance. This result shows that the stronger the audits, the higher the tax compliance. In addition to these, although it is not statistically significant for the EU countries, this result finds evidence for the literature of audit's negative effect on compliance. These findings are due to the fact that EU countries have higher levels of socioeconomic development in comparison to OECD countries.

It is found that the variable of freedom to trade internationally is statistically significant for both country groups and has a significant positive effect as expected. This finding is a result of the proliferation of international tax treaties, multilateral institutions, and agreements due to the increasing globalization in today's economy. The common model for transfer pricing derives from agreements, joint investment rules, common policies in the fight against tax havens, determination of a harmonious taxation regime, and joint efforts to close the gaps in taxation. In addition, it may occur because of the fact that the countries in both of the groups are the most developed countries and they have had an important role in world's economy for years.

The results of the rule of law is statistically significant for the EU and OECD. As this variable shows the power of authority and how strong the rules in a country are, these results confirm the basic assumption of the slippery slope framework. Additionally, the impact of the variable 


TJSSS

on tax compliance is high and positive because these countries have the highest power level of the government, the authorities and the rule of law as a structure of the society.

Education index is only statistically significant for OECD but has a negative effect on both country groups. As the citizens in these countries have the highest education levels in the world, they may choose to use their high level of education, knowledge to take advantage of the legal gaps for tax evasion or ship their investments to other countries that have lower tax rates or audits by using their knowledge rather than being more complaint.

Gender inequality index is a social variable in the model and is thought to be one of the variables that indicate the level of equality in a country. When the index degree increases, this means that inequality level decreases. That's why it is expected that increasing level of index decreases tax compliance, which means an adverse effect. If we come to the results, the index has a negative affect on EU countries as expected. However, it can be remarked that it is not a very effective variable in increasing tax compliance due to fiscal sociology as it has a very small effect compared to other variables. On the other hand, it has a statistically significant and positive effect for OECD countries. It is an unexpected result for this variable and it may be noted that it is the least effective variable for tax compliance for this group.

The social capital variable, which represents the level of interdependence of the society/citizens, is found to be statistically significant and has positive effect for both of the groups. The effects of the variable match with the expected results and this is one of the most important variables in the model because of its coefficient. These findings are expected because citizens in these countries trust in the government and each other, which mean that they live in safe and feel connected to each other and to their country. That's why, their feelings direct them to behave in a compliant way.

\section{CONCLUSION}

The most important priority of fiscal sociology is to search the interaction between social structure and fiscal policies. This is due to the fact that tax systems reflect the same characteristics, in other words, a taxation system using the same fundamentals as the society itself will be met with less resistance and thus will be more successful.

Considering the fact that one of the variables showing the success level of the tax system is tax compliance, the relationship between the tax system and the components of the structure of the society is analyzed in this study in the context of the variable of tax compliance. In this study, it is aimed to measure the effects of socio-economic determinants which constitute the structure of the society on tax compliance by considering fiscal sociology.

A general review of the results of the analysis indicate that a group of variables that determine the structure of the society should bear more weight in policy making than other variables and this all depends on the structure of the society in the framework of fiscal sociology. The classification depending on the EU and OECD also supports the importance of making tax regulations by taking into consideration the structural elements. These results emphasize the view that the internal dynamics, social and economic order, and governance structure of a country must be given high priority and consideration in formulating tax policies and regulations in accordance with fiscal sociology. 


\begin{tabular}{l} 
Year:4, Volume:4, Number:7 / 2020 \\
\hline $\begin{array}{l}\text { The } \\
\text { Social } \\
\text { Science }\end{array}$
\end{tabular}

\section{REFERENCES}

Allingham, M. G. and Sandmo, A. (1972). "Income Tax Evasion: A Theoretical Analysis". Journal of Public Economics, 1, 323-338.

Alm, J., Bernasconi, M., Laury, S., Lee, D. J., Wallace, S. (February 2016). "Culture, Compliance, and Confidentiality: A Study of Taxpayer Behavior in the United States and Italy". University Ca' Foscari of Venice, Dept. of Economics Research Paper Series, No. 36, 1-35.

Alm, J., Jackson B. R. and Mckee, M. (March 1992). "Estimating The Determinants of Taxpayer Compliance With Experimental Data". National Tax Journal, 45(1), 107114.

Andrighetto, G., Zhang, N., Ottone, S., Ponzano, F., D'Attoma, J., Steinmo, S. (March 2016). "Are Swedes more honest than Italians? Ordinary Dishonesty in Cross-Country Tax Compliance Experiments". Frontiers in Psychology, 7(472).

Backhaus, J. G., 2001. "Fiscal Sociology: What For?”. American Journal of Economics and Sociology, 61(1), 1-33.

Backhaus, J. G., 2004. “Joseph A. Schumpeter's Contributions in the Area of Fiscal Sociology: A First Approximation”. Journal of Evolutionary Economics, 14, 143-151.

Batrancea, L. M., Nichita, R. A., Batrance, I., Moldovan, B. A. (2012). "Tax Compliance Models: From Economic to Behavioral Models". Transylvanian Review of Administrative Sciences, 36, 13-26.

Bobek, D. D., Hageman, A. M., Kelliher, C. F. (2013). "Analyzing the Role of Social Norms in Tax Compliance Behavior". Journal of Business Ethics, 115, 451-468.

Brun, B. L. (2013). "Fiscal Sociology: An Innovative Approach of Citizenship and Democracy Design". Essentials of Fiscal Sociology: Conception of an Encyclopedia (Ed. J. G. Backhaus). Frankfurt, 11-14.

Campbell, J. L., 1993. "The State and Fiscal Sociology”. Annual Review of Sociology, 19, 163-185.

Çevik, S. (July-December 2012). "Taxpayer Interaction with the State and Society, Individual Norms and Tax Ethics". Journal of Public Finance, 163, 258-289.

D'Attoma, J., Volintiru, C., Steinmo, S. (April-June 2017). "Willing to share? Tax compliance and gender in Europe and America". Research and Politics, 1-10.

D'Attoma, J. (2018). "What explains the North-South divide in Italian tax compliance? An experimental analysis". Acta Politica, 54, 104-123.

Dhami, S. and al-Nowaihi, A. (2006). "Why Do People Pay Taxes? Prospect Theory Versus Expected Utility Theory". Journal of Economic Behavior \& Organization, 64(1), 171192.

Dubin, J. A., Graetz, M. J., Wilde, L. L. (May 1987). “Are We A Nation of Tax Cheaters? New Econometric Evidence on Tax Compliance". American Economic Review, AEA Papers and Proceedings, 77(2), 240-245.

Dubin, J. A. and Wilde, L. L. (1988). "An Empirical Analysis of Federal Income Tax Auditing and Compliance". National Tax Journal, 41(1), 61-74. 
Feld, L. P. and Frey, B. S. (2002). "Trust Breeds Trust: How Taxpayers Are Treated". Economics of Governance, 3, 87-99.

Giddens, A. (2011). Sociology (Sixth Edition). Cambridge: Polity Press.

Grasmick, H. G. and Green, D. E. (1980). "Legal Punishment, Social Disapproval and Internalization as Inhibitors of Illegal Behavior". Journal of Criminal Law and Criminology, 71(3), 325-335.

Gwartney, J., Lawson, R., Hall, J., Murphy, R. (2018). Economic Freedom of the World: 2018 Annual Report. Fraser Institute. Available: https://www.fraserinstitute.org/studies/economic-freedom, 15.11.2019.

Juan, A., Lasheras, M. A., Mayo, R. (1994). "Voluntary tax compliant behavior of Spanish income tax payers". Public Finance, 49, 90-105.

Kahneman, D. and Tversky, A. (March 1979). "Prospect Theory: An Analysis of Decision under Risk". Econometrica, 47(2), 263-292.

Kamdar, N. (December 1995). "Information Reporting and Tax Compliance: An Investigation Using Individual TCMP Data”. Atlantic Economic Journal, 23(4), 278-292.

Kirchler, E., Hoelzl, E., Wahl, I. (2008). "Enforced Versus Voluntary Tax Compliance: The “'Slippery Slope'’ Framework”. Journal of Economic Psychology, 29, 210-225.

Kolodziej, S. (2011). "The Role of Education in Forming Voluntary Tax Compliance". General and Professional Education, 1, 22-25.

Legatum Institute (November 2017). The Legatum Prosperity Index 2017 (Eleventh Edition).

Martin, I. W., A. K. Mehrotra, Prasad, M. (2009). "The Thunder of History: The Origins and Development of The New Fiscal Sociology". The New Fiscal Sociology-Taxation in Comparative and Historical Perspective (Ed. I. W. Martin, A. K. Mehrotra, M. Prasad). Cambridge: Cambridge University Press, 1-27.

Mason, R. and Calvin, L. D. (1984). "Public Confidence and Admitted Tax Evasion". National Tax Journal, XXXVII, 489-496.

McLure, M. (2003). "Fiscal Sociology". Economics Program School of Economics and Commerce, The University of Western Australia, Discussion Paper, No. 03.16, 1-10.

Mugler, J. (2019). "Regulatory Capture? Fiscal Anthropological Insights into the Heart of Contemporary Statehood”. The Journal of Legal Pluralism and Unofficial Law, 50, 117.

Mumford, A. (May 2019). Fiscal Sociology at the Centenary-UK Perspectives on Budgeting, Taxation and Austerity. United Kingdom: Palgrave Macmillan, Palgrave Socio-Legal Studies.

Muter, N. B., Sakınç, S., Çelebi, A. K. (1993). "Taxpayers' Attitudes and Behaviors Against Taxes-A Survey on Taxpayers in Manisa". Celal Bayar University Faculty of Economics and Administrative Sciences Department of Finance, Manisa.

Nuta, A. C. (2018). "Some Considerations on Fiscal Sociology". EIRP Proceedings, 12, 392395.

OECD (October 2004). Compliance Risk Management: Managing and Improving Tax Compliance. Guidance Note. Paris. 
OECD (2014). Measures of Tax Compliance Outcomes: A Practical Guide. Paris: OECD Publishing.

Padgett, J. (July 1981). "Hierarchy and Ecological Control in Federal Budgetary Decision Making”. American Journal of Sociology, 87(1), 75-129.

Park, C. G. and Hyun, J. K. (2003). "Examining The Determinants of Tax Compliance by Experimental Data: A Case of Korea". Journal of Policy Modeling, 25, 673-684.

PricewaterhouseCoopers (PwC) and The World Bank, 2009. Paying Taxes 2010.

PricewaterhouseCoopers (PwC) and The World Bank, 2010. Paying Taxes 2011.

PricewaterhouseCoopers (PwC) and The World Bank, 2011. Paying Taxes 2012.

PricewaterhouseCoopers (PwC) and The World Bank, 2012. Paying Taxes 2013.

PricewaterhouseCoopers (PwC) and The World Bank, 2013. Paying Taxes 2014.

PricewaterhouseCoopers (PwC) and The World Bank, 2014. Paying Taxes 2015.

PricewaterhouseCoopers (PwC) and The World Bank, 2015. Paying Taxes 2016.

PricewaterhouseCoopers (PwC) and The World Bank, 2016. Paying Taxes 2017.

PricewaterhouseCoopers (PwC) and The World Bank, 2017. Paying Taxes 2018.

PricewaterhouseCoopers (PwC) and The World Bank, 2018. Paying Taxes 2019.

Pukeliene, V. and Kazemekaityte, A. (2016). "Tax Behaviour: Assessment of Tax Compliance in European Union Countries". Ekonomika, 95(2), 30-56.

Saad, N. (2014). "Tax Knowledge, Tax Complexity and Tax Compliance: Taxpayers' View”. Social and Behavioral Sciences, 109, 1069-1075.

Saruç, N. T. (January 2015). Tax Compliance: Theory and Politics. Ankara: Seçkin Publishing.

Scholz, J. T. and Lubell, M. (April 1998). "Trust and Taxpaying: Testing the Heuristic Approach to Collective Action". American Journal of Political Science, 42(2), 398417.

Song, Y. and Yarbrough, T. E. (September/October 1978). "Tax Ethics and Taxpayer Attitudes: A Survey". Public Administration Review, 38(5), 442-452.

Spicer, M. W. and Becker, L. A. (June 1980). "Fiscal Inequity and Tax Evasion: An Experimental Approach". National Tax Journal, 33(2), 171-175.

United Nations Development Programme (UNDP), http://hdr.undp.org/sites/default/files/hdr2018_technical_notes.pdf, 25.11.2019.

Vasquez, I. and Porcnik, T. (2018). The Human Freedom Index 2018-A Global Measurement of Personal, Civil and Economic Freedom. Cato Institute, The Fraser Institute, and the Friedrich Naumann Foundation for Freedom. Available: https://www.fraserinstitute.org/sites/default/files/human-freedom-index-2018.pdf, 15.11.2019.

Yitzhaki, S. (1974). “A Note on Income Tax Evasion: A Theoretical Analysis". Journal of Public Economics, 3, 201-202. 
Yong, S. and Martin, F. (2016). "Tax Compliance and Cultural Values: The İmpact of "Individualism and Collectivism" on The Behaviour of New Zealand Small Business Owners". Australian Tax Forum, 31, 289-320.

Appendix. Results of Heteroscedasticity, Autocorrelation, Interdivisional Correlation

\begin{tabular}{|c|c|}
\hline \multicolumn{2}{|r|}{$\mathbf{E U}$} \\
\hline Heteroscedasticity & $\begin{array}{lll}\text { W0 }=5.9476162 & \mathrm{df}(27,224) & \mathrm{Pr}>\mathrm{F}=0.00000000 \\
\mathrm{~W} 50=2.4997007 & \mathrm{df}(27,224) & \operatorname{Pr}>\mathrm{F}=0.00013564 \\
\mathrm{~W} 10=5.9476162 & \mathrm{df}(27,224) & \mathrm{Pr}>\mathrm{F}=0.00000000\end{array}$ \\
\hline Autocorrelation & $\begin{array}{l}\text { modified Bhargava et al. Durbin-Watson }=.80547396 \\
\text { Baltagi-Wu LBI }=1.1857945\end{array}$ \\
\hline Interdivisional correlation & $\begin{array}{l}\text { Pesaran's test of cross sectional independence }=6.747 \text {, } \\
\operatorname{Pr}=0.0000\end{array}$ \\
\hline \multicolumn{2}{|r|}{ OECD } \\
\hline Heteroscedasticity & $\begin{array}{l}\text { chi2 }(34)=3377.46 \\
\text { Prob }>\text { chi } 2=0.0000\end{array}$ \\
\hline Autocorrelation & $\begin{array}{l}\text { modified Bhargava et al. Durbin-Watson }=.88002079 \\
\text { Baltagi-Wu LBI }=1.2911963\end{array}$ \\
\hline Interdivisional correlation & $\begin{array}{l}\text { Pesaran's test of cross sectional independence }=7.061 \text {, } \\
\operatorname{Pr}=0.0000\end{array}$ \\
\hline
\end{tabular}

